\title{
Environmental Control, Internal Auditor and Good University Governance
}

\author{
Sukirman ${ }^{l *}$, Retnoningrum Hidayah $^{l}$, Dhini Suryandari ${ }^{1}$, Ima Nur Kayati ${ }^{2}$ Bisri \\ Rahayuningsih ${ }^{1}$, Sarifa Aini ${ }^{1}$, Nanda Riski $^{1}$, Muslikhin ${ }^{3}$ \\ ${ }^{1}$ Faculty of Economics, Universitas Negeri Semarang, Indonesia \\ ${ }^{2}$ Internal Control Unit, Universitas Negeri Semarang, Indonesia \\ ${ }^{3}$ PT. Asuransi Kredit Indonesia (ASKRINDO) Cabang Semarang, Indonesia
}

\begin{abstract}
The Environmental control is essential for the achievement of organizational goals. Environmental control includes a management system, human resources, and information system. Hence, this research aims to examine the effect of an internal auditor and environmental control on good university governance. In addition, this research examines the role of the internal auditor on environmental control. The research sample technique used convenience sampling with a total sample of 121 respondents. This study uses primary data. The hypothesis test uses WarpPLS 7. The results show that internal auditor and environmental control affect good university governance. Furthermore, this study proves that the internal auditor could play a significant role in encouraging environmental control to run well and achieve the institution's goal. Therefore, all organizations should improve the effectiveness of internal auditors. Future research is expected to add moderating variables like organization commitment.
\end{abstract}

\section{Introduction}

Good governance is an important key to achieving high agency performance. Good governance can be defined as the management of an institution or agency free from all types of corruption and fraud [1]. In 2019, a good governance assessment was carried out in companies listed on the Indonesia Stock Exchange. The assessment results show that there are only ten companies that have an index value of $97.5 \%$. It is a big question of how only ten companies in Indonesia with trillions of assets may meet the criteria of good corporate governance. What about the governance in education? Whereas good governance is the main factor in minimizing fraud, which results in significant losses to an organization.

According to a survey [2], corruption is a fraud that contributes to Indonesia's largest loss $(70 \%)$ compared to other fraudulent schemes such as $21 \%$ asset misuse and $9 \%$ fraudulent financial statements. Therefore, good governance must be implemented in all organizational lines, including government agencies, private companies, schools, and universities. Good governance is able to reduce the level of corruption that may occur within the organization [3]. Believed that three aspects build good governance, namely

*Corresponding author: sukirman3002@mail.unnes.ac.id 
supervision, control, and inspection. Therefore, good governance also deserves to be applied at the tertiary level. It is because fraud has also penetrated the high education sector. From 2015 to 2019, there have been some corruption cases within universities, resulting in state losses amounting to Rp.81.09 billion [4].

This indicates that implementing good governance in higher education is crucial to minimize other similar fraud incidents. The implementation of good governance is, of course, inseparable from adaptation based on typical characteristics of each organization and values they embrace, which are: [1] openness in management and reporting activities, or what is often called transparency, [2] proper accountability processes, (3) responsibility in carrying out all activities, [4] holding principles without any pressure from other parties or what is called independence, and [5] placing everything according to their rights or being fair [5].

Good governance is closely connected with fraud. The better good governance, the lower the level of fraud. In other words, fraud is the result of poor company management. Based on [2], several things can find fraud, including the application of the whistleblowing system, internal audit, external audit, management review, rotation, inspection, and others. Therefore, higher education institutions also have examination functions divided into two; internal and external examination. Next, the scope of environmental control can be defined into five components, namely control environment, risk assessment of all activities of organizations that are vulnerable to negative impacts in the future, proper management of information system starting from information flow to processing information into data, and controlling processes for all organizational activities to fit in the achievement of company goals, and the last is monitoring the entire organization's business processes and ensuring that they are all in accordance with the company's strategies and goals achievement [6].

There have been some studies related to governance; there are some differences in results, such as [7], who stated that an effective internal auditor always supports a tertiary institution with good governance. Furthermore, [8] believed that the implementation of good governance is influenced by internal organizational control [9]. Explained that the role of internal auditors has a positive effect on the effectiveness of the internal control system of higher education [1]. Described, internal auditors have an effect on good governance. Meanwhile, [10] was sure that internal control has a negative effect on the implementation of fraud. It means that the better the internal control, the lower the fraud that may occur. Also, [11] believed that the auditor's role in auditing is to improve good governance [12]. Stated that internal control, internal audit, and organizational commitment have a significant positive relationship with good governance.

Besides, internal control has a significant role in the control environment. Internal auditors must ensure that the control environment is running well. Environmental control is an important aspect of the implementation of good governance. The absence of a system that can control the work environment will have fatal consequences for company performance. Environmental control includes a control system, organizational rules or culture, business process strategies, communication, and risk management. They can significantly influence the implementation of good governance. Environmental control does not only focus on internal human resources but also organizational culture, the use of accounting information systems, and various kinds of threats and opportunities from external parties that we can capture. Agency theory states that a conflict of interest between a manager and a principal will undoubtedly occur in an organization. The manager indeed has more detailed information than the principal to trigger actions to benefit himself [6]. Therefore, there should be reasonable internal control. The duties and functions of internal control are usually carried out by the internal auditor [7]. This showed that the better the role of internal auditors, the better the achievement of good university governance. 
H1: Internal auditor influences environmental control

H2: Environmental control influences good governance

$H 3$ : Internal auditor influences good governance

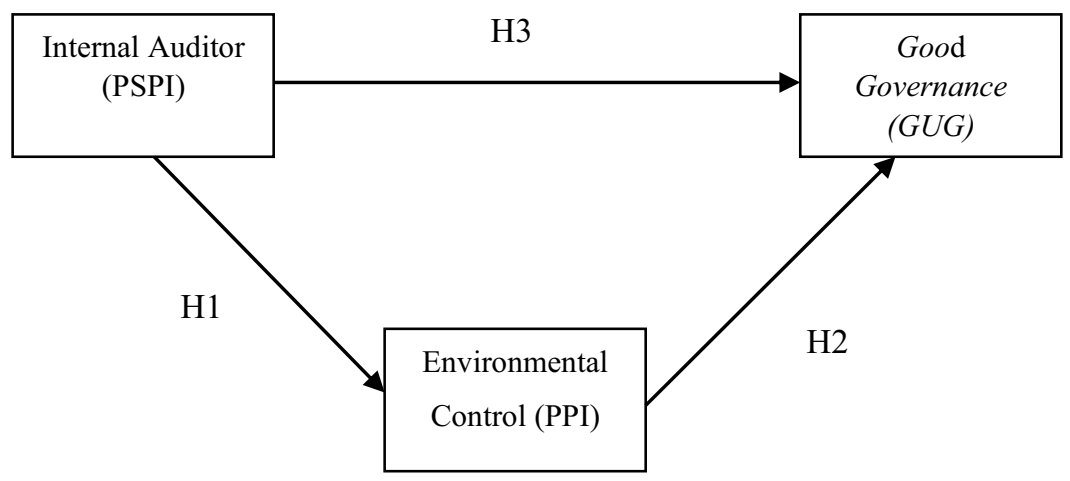

Fig. 1. Research Model.

\section{Method}

The research population is employees of the accounting, finance, assets and planning sections and those involved in the preparation of financial accountability reports at Universitas Negeri Semarang. The sampling technique used is convenience sampling. There are 121 respondents. Furthermore, the hypotheses are tested using the influence test through WarpPls. The dependent variable is good university governance. Meanwhile, the independent variables consist of environmental control and internal auditor. This research uses WarpPLS 7.0 with a linear research model.

Table 1. Variables Operational Definition.

\begin{tabular}{|l|l|l|}
\hline \multicolumn{1}{|c|}{ Variable } & \multicolumn{1}{|c|}{ Indicator } & \multicolumn{1}{c|}{ Measurement } \\
\hline $\begin{array}{l}\text { Good university governance } \\
\text { (GUG) }\end{array}$ & $\begin{array}{l}\text { Transparency; accountability; } \\
\text { responsibility; independency; fairness }\end{array}$ & Likert scale, 1 to 5 \\
\hline Environmental control (PPI) & $\begin{array}{l}\text { Human resources, asset resources, } \\
\text { information systems and others. } \\
\text { Controlling; risk assessment; information } \\
\text { system; control activities }\end{array}$ & Likert scale, 1 to 5 \\
\hline Internal auditor (PSPI) & $\begin{array}{l}\text { The role of auditor internal in carrying } \\
\text { out their duties effectively. Independence, } \\
\text { internal audit work scope; management; } \\
\text { professional skill; audit task }\end{array}$ & Likert scale, 1 to 5 \\
\hline
\end{tabular}




\section{Results and Discussion}

The evaluation of the measurement model/ outer model shows that the significance value of the weight has a p-value of $0.001<0.05$. Then, the multicollinearity test shows a VIF value of $0.00<2.5$. Hence, the measurement of formative constructs is declared feasible.

The evaluation of the structural model/ inner model shows the predictive relevance (Q2) value of $0.877>0$. It means this model is valid to be used as a prediction. The test result of the coefficient of determination (R2) is 0.874. It means the internal auditor and environmental control variables can explain the excellent governance variable by $87.4 \%$. The model fit test also shows the APC value with a p-value $<0.001$, where $<0.05$ and an ARS value with a p-value $<0.001$ where $<0.05$ and an AVIF value of 3.852 where $<5$, which means the research model is acceptable.

Table 2. Results of Outer Model.

\begin{tabular}{|c|c|c|c|}
\hline Result & $\begin{array}{c}\text { Internal Auditor } \\
\text { (PSPI) }\end{array}$ & $\begin{array}{c}\text { Environmental } \\
\text { Control (PPI) }\end{array}$ & $\begin{array}{c}\text { Good University } \\
\text { (GUG) }\end{array}$ \\
\hline VIF & 0.000 & 0.000 & 0.000 \\
\hline P value & $<0.001$ & $<0.001$ & $<0.001$ \\
\hline Composite reliable. & 1.000 & 1.000 & 1.000 \\
\hline Cronbach's alpha & 1.000 & 1.000 & 1.000 \\
\hline Avg.var.extrac. & 1.000 & 1.000 & 1.000 \\
\hline
\end{tabular}

Table 3. Results of Inner Model.

\begin{tabular}{|c|c|}
\hline Results & Value \\
\hline $\mathrm{Q}^{2}$ & 0.877 \\
\hline $\mathrm{R}^{2}$ & 0.874 \\
\hline APC & 0.607 \\
\hline AARS & 0.805 \\
\hline AVIF & 3.852 \\
\hline
\end{tabular}

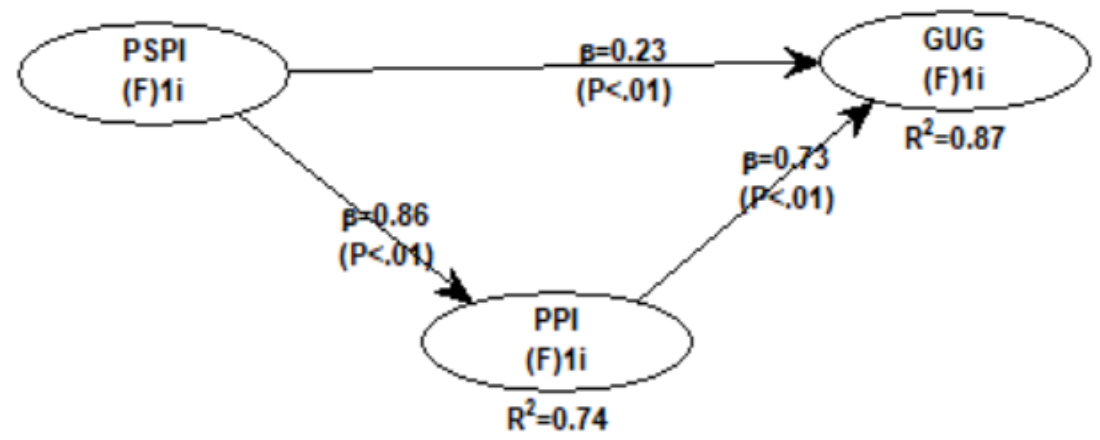

Fig. 2. Hypothesis Test Result. 
Based on the hypothesis test result, the effect of the internal auditor on environmental control has a p-value lower than 0.01. It means that an internal auditor affects environmental control. The more effective the role of internal auditors in an organization is, the better the existing environmental control is to improve the effectiveness of employees' performance. Environmental control is important because it is related to how the surrounding conditions and organizational culture can positively impact performance.

Next, the p-value for the influence of environmental control on good governance is lower than 0.01 . This means environmental control affects good governance. The better the organizational control environment, such as control systems, risk assessment, information systems, and others, the better the good governance index will be. This is in line with [13, $14,12,15]$. Moreover, environmental control can improve the effectiveness of employees in carrying out their duties and functions. Clear rules, well-organized work culture, and control of bad aspects can enhance the efficiency and effectiveness of resources.

In addition, the relationship between the internal auditor and good university governance shows that the p-value is lower than 0.01 . These results prove that internal auditors can have a significant influence on the implementation of good university governance. This indicates that the role of internal auditors in an organization is very crucial. Its existence can ease the workload of the leadership in monitoring the condition of the company. Furthermore, internal auditors can also impact external parties, such as independent auditors, in obtaining information related to the company. Independent auditors need the most important information in understanding the organization's business processes to achieve the duties of an independent auditor. It is in line with $[12,15,16,17$, $18,19]$. Going more depth, corporate governance principles can be used as guidelines in improving the performance and sustainability of a university. This is in accordance with $[20]$ that universities with good governance practices can create a good culture to survive in a fully competitive era.

\section{Conclusions}

The research findings show internal auditor influences other control environments. Furthermore, environmental control affects good governance. Moreover, internal auditor has a positive impact on the implementation of good governance in higher education. This research contributes to the knowledge of good governance implementation. Hence, good governance is very beneficial for all types of organizations. In addition, this research contributes to stakeholders related to higher education, such as university employees, students, management, to the ministry of higher education. They must cooperate reasonably to enhance the effectiveness of environmental control and internal auditors to achieve good governance. Future research could add other such as the financial condition of higher education, assessment from the external auditor, and the implementation of enterprise risk management.

\section{References}

1. D. N. Rahmatika, “The Impact of Internal Audit Function Effectiveness on Quality of Financial Reporting and its Implications on Good Government Governance Research on Local Government Indonesia," Res. J. Financ. Account., vol. 5, no. 18, (2014)

2. ACFE, "Survai Fraud Indonesia," Association of Certified Fraud Examiners, 2019. https://acfe-indonesia.or.id/survei-fraud-indonesia/ (accessed Feb. 01, 2020).

3. [3] Mardiasmo, Indonesian Public Sector Accounting. Jogjakarta, Indonesia: Andi, (2004) 
4. M. A. Puspitasari, "ICW Temukan Lima Modus Korupsi di Kampus," 2020. [Online]. Available: https://koran.tempo.co/read/nasional/453801/kasus-dugaan-korupsi-dikampus? (2020)

5. S. Wijatno, Pengelolaan Perguruan Tinggi Secara Efisien, Efektif dan Ekonomis untuk Meningkatkan Penyelenggaraan Pendidikan dan Mutu Lulusan. Jakarta: Salemba Empat, (2009)

6. T. Tuanakotta, Audit Berbasis ISA (International Standard on Auditing). Jakarta: Salemba Empat, (2013)

7. N. D. Puspitarini, "Peran Satuan Pengawasan Intern dalam Pencapaian Good University Governance pada Perguruan Tinggi Berstatus PK-BLU," Account. Anal. J., vol. 1, no. 2, 2012, doi: https://doi.org/10.15294/aaj.v1i2.706. (2012)

8. F. Widjaja and R. H. Mustamu, "Pengaruh Sistem Pengendalian Internal terhadap Implementasi Prinsip-prinsip Good Corporate Governance pada Perusahaan Insdustri Keramik," AGORA, vol. 2, no. 1, (2014)

9. N. Wardah, "Pengaruh Peran dan Kinerja Auditor Internal terhadap Efektivitas Sistem Pengendalian Internal," Universitas Islam Syarif Hidayatullah, (2015)

10. J. Arifin, "Determinan Kecurangan Akuntansi di Lingkungan Perguruan Tinggi," J. Ekon. dan Keuang., vol. 4, 2020, doi: https://doi.org/10.24034/j25485024.y2020.v4.i2.4035. (2020)

11. R. R. Satyal, "Audit Profile: Office of The Auditor General of Nepal International Journal of Government Auditing," ABI/ Inf., vol. 33, no. 4, p. 26, (2006)

12. E. Suyono and E. Hariyanto, "Relationship Between Internal auditor, Internal Audit, and Organization Commitment With Good Governance: Indonesian Case.," ChinaUSA Bus. Rev., vol. 11, no. 9, pp. 1237-1245, 2012, doi: 10.17265/15371514/2012.09.006. (2012)

13. J. Stewart and N. Subramaniam, "Internal Audit Independence and Objectivity: Emerging Research Opportunities," Manag. Audit. J., vol. 25, no. 4, pp. 328-360, 2010, doi: https://doi.org/10.1108/02686901011034162. (2010)

14. P. Nila and Viriyanti, "The Relationship Between Internal auditor and Good Corporate Governance (Survey on State Owned Enterprises in Bandung, Indonesia)," Widyatama Univ. Work. Pap., (2008)

15. Suriyani and Zainuddin, "Pengaruh Satuan Pengawasan Internal (SPI) dan Penerapan Internal auditor terhadap Pencapaian Good University Governance (GUG) Pada Universitas Islam Negeri Raden Fatah Palembang," J. Ilm. Bina Manaj., vol. 4, no. 1, 2021, doi: https://doi.org/10.33557/jibm.v4i1.1279. (2021)

16. J. V. Carcello, D. R. Hermanson, and K. Raghunandan, "Changes in Internal Auditing During The Time of The Major US Accounting Scandals," Int. J. Audit., vol. 9, no. 2, pp. 117-127, (2005)

17. A. Virginia, K. Eleni, P. Dimitrios, and X. Chrysoula, "The Role of Financial Accounting Information in Strengthening Corporate Control Mechanism to Alleviate Corporate Corruption," Univ. Maced. Work. Pap., (2009)

18. N. Yasin, M. J. Ghaneem, and L. Rustom, "The Role of Internal Audit Function in Corporate Governance: An Empirical Study on Commercial Banks in Lebanon," (2011)

19. F. N. Yudianti and I. H. Suryandari, "Internal auditor and Risk Management in Ensuring Good University Governance," J. Educ. Vocat. Res., vol. 6, no. 2, pp. 6-12, 2015, doi: https://doi.org/10.22610/jevr.v6i2.183. 
20. R. de Oliveira, J. Leitao, and H. Alves, "Corporate Governance and Sustainability in HEIs," Emerald Publ. Ltd., vol. 22, 2020, doi: https://doi.org/10.1108/S2055364120200000022016. 